\title{
Overview of Body Mass Index and Blood Pressure of Medical Science Faculty Student in Prima Indonesia University, 2017
}

\author{
Fautia Ristina ${ }^{1}$, Wienaldi ${ }^{2}$ \\ 1,2Medical Science Faculty, Universitas Prima Indonesia
}

\begin{abstract}
:
The aims of this study discussed overview of body mass index and blood pleasure in Medical Science Faculty Student. This research is a descriptive study with a cross-sectional study design, namely how to approach, observe or collect data at the same time 10. Based on the research results, it was found that the majority of BMI students from the Faculty of Medicine UNPRI Medan class 2017 were normal, namely 64 people (64.6\%), then followed by students with an overweight BMI of 29 people $(29.3 \%)$, underweight and obese respectively. only 3 people (3.0\%). Based on the results of the study, it was found that the majority of the blood pressure of the 2017 UNPRI Medan Faculty of Medicine students was completely normal $(100 \%)$.
\end{abstract}

\section{Keywords:}

overview; body mass index; blood pressure; student

\section{Introduction}

Epidemiological and demographic transitions in modern times have led to lifestyle changes that have become a threat in the health sector. Unhealthy lifestyle changes such as smoking, low physical activity, high consumption of fatty foods and alcohol consumption are thought to be risk factors for Non-Communicable Diseases (PTM). Non-communicable disease (PTM) is a chronic disease that is not transmitted from person to person. Every year, as many as 41 million people die from PTM, 15 million of them are aged 30-69 years and more than $85 \%$ of these events occur in developing countries. In Indonesia, in 1995-2007 (12 years) there was an epidemiological transition in which deaths due to non-communicable diseases increased, while deaths from infectious diseases decreased.

Body mass index (BMI) is a simple measuring tool for monitoring the nutritional status of adults in relation to excess and underweight. The use of BMI only applies to adults over 18 years of age. BMI can describe the level of adiposity or fat accumulation in a person's body. Excessive fat in the body can cause health risks. The World Health Organization (WHO) has recommended that an individual who is overweighting (overweight) is closely associated with an increased risk of several non-communicable diseases; this is based on body mass index (BMI). BMI is a measure of weight that is relatively easy to obtain, and is used to assess a person as thin or overweight. BMI can also be associated with the risk of health status and mortality rate. The prevalence of obesity in Indonesia based on the results of research conducted by RISKESDAS (Basic Health Research) in 2018 shows that the prevalence of a number of health services has increased compared to Riskesda 2013. High blood pressure or hypertension increased from $25.8 \%$ to $34.1 \%$. The prevalence of obesity also jumped from $14.8 \%$ to $21.8 \%$, in line with the development of science and technology which has increased and the economic growth and population growth are accelerating. Hypertension is also known as high blood pressure a condition in which the blood vessels can constantly increase the pressure. Hypertension is a serious medical condition and can increase the risk of 
cardiovascular disease, stroke, end-stage kidney disease, and adrenal medulla disease. Hypertension is the leading cause of premature death worldwide, with more than 1 in 4 men and 1 in 5 women and more than one billion people having the condition. The World Health Organization (WHO) predicts that currently the prevalence of hypertension globally is $22 \%$ of the world's total population. Of the number of sufferers, only less than a fifth who make efforts to control their blood pressure. The African region has the highest prevalence of hypertension at $27 \%$. Southeast Asia is in the 3rd position with a prevalence of $25 \%$ of the total population only less than a fifth who makes efforts to control their blood pressure. The African region has the highest prevalence of hypertension at $27 \%$. Southeast Asia is in the 3 rd position with a prevalence of $25 \%$ of the total population only less than a fifth who make efforts to control their blood pressure. The African region has the highest prevalence of hypertension at $27 \%$. Southeast Asia is in the 3 rd position with a prevalence of $25 \%$ of the total population.

Increased blood pressure is effectively modified through antihypertensive drugs and lifestyle modifications such as limiting sodium intake, alcohol, and regular exercise. A healthy lifestyle can reduce blood pressure without dangerous side effects. In addition, it can improve overall cardiovascular health. Thus, lifestyle modification is highly recommended for hypertensive patients regardless of they are being treated with antihypertensive drugs. Increased prevalence of hypertension based on measurement methods also occurred in almost all provinces in Indonesia. The highest increase in prevalence was in the Province of DKI Jakarta at $13.4 \%$, South Kalimantan at $13.3 \%$, and West Sulawesi at $12.3 \%$. The results of Riskesdas 2018 show that South Kalimantan Province has the highest prevalence of 44, 13\% followed by West Java at 39.6\%, East Kalimantan at 39.3\%. Papua Province had the lowest hypertension prevention at $22.2 \%$, followed by North Maluku at $24.65 \%$ and North Sumatra at $29.19 \%$. Based on the initial survey, the Faculty of Medicine UNPRI Medan is one of the Medical Faculties in North Sumatra Province which has various activities and facilities. UNPRI Faculty of Medicine students have a busy schedule. In addition to academic activities, they also have Early Clinical Exposure (ECE) activities which are mandatory. The facilities available at UNPRI are K3 and Café Taria which serve fast food and junk food, which can affect body mass index so that there is a risk of health problems. After conducting an initial survey on several UNPRI Faculty of Medicine students, information was obtained that the majority had experienced an abnormal BMI. Researchers feel this research is important to do to increase students' attention about body mass index and blood pressure. Based on the background description above, the researcher was interested in conducting research on the description of body mass index and blood pressure in students at the Faculty of Medicine, UNPRI Medan, and Batch 201

\section{Review of Literatures}

\subsection{Body Mass Index (BMI)}

Body mass index (BMI) or body mass index (BMI) is a measure of body fat based on height and weight that applies to adult men and women. Body mass index (BMI) is a simple index of body weight for height used to classify overweight and obesity in adults. BMI is defined as a person's weight in kilograms divided by the square of their height in meters (kg / $\mathrm{m})$. Body Mass Index (BMI) is an accurate calculation of the amount of normal body weight, calculated from a person's height and weight. Body Mass Index (BMI) is a simple tool for monitoring the nutritional status of adults, especially those related to underweight and overweight. The use of BMI only applies to adults over 18 years of age. BMI cannot be applied to infants, children. 
BMI measurement is the cheapest and easiest way to detect obesity problems in an area. The problem of obesity is currently increasing with the increasing welfare of the community and the increase in technological advances that allow people's activities to decrease. The increase in the problem of obesity is closely related to various chronic degenerative diseases, such as hypertension, diabetes, coronary heart disease, cancer, etc. BMI measurements can be performed on children, adolescents and adults. In children and adolescents, BMI measurement is closely related to age, because with changes in age there are changes in body composition and body density. Therefore, in children and adolescents, the $\mathrm{BMI}$ indicator according to age is used, usually symbolized by BMI / U.

The term anthropometry comes from "anthro" which means human, and "metri" which means size. Jellife (1996) in Supariasa (2001), states: "Nutritional Anthropometry is Meansurement of the Variations of the Physical Dimensions and the Gross Cmposition of the Human Body atDifferent Age Levels and Degree of Nutrition". Based on the above definition, it can be concluded that nutritional anthropometry is related to various measurements of body dimensions and body composition from different ages and nutritional levels. Anthropometry is the measurement of body parts. Changes in the dimensions of the body reflect the state of health and well-being of a particular person or population. Anthropometry is used to assess and predict nutritional status, performance, health and survival of a person and reflects the socio-economic condition or welfare of the population. Anthropometry can be used for various purposes, depending on the anthropometric indicator chosen. For example, body mass index (BMI) is an indicator of thinness and obesity.

According to (Adriani and Wirjatmadi, 2012), there are two measures that are considered appropriate, which are internationally recognized in anthropometry, namely:

\section{Weight}

Body weight is the most important measure and most widely used in checking health. Body weight is the result of an increase (the sum) of all bone tissue, muscle, fat, body fluids, and others. For weighing the body of children, adolescents and adults using body scales, for example, bathroom scales, electric scales, standard detection, and health smic scales. The person to be weighed will wear clothing made of light material and not be done after eating.

\section{Height}

Height provides a picture of bone growth with age. Height is not much affected by sudden changes, because height is the result of accumulative growth from birth, and therefore provides a history of past nutritional status. Measurement of height in adolescents used microtoise. The person being measured should not use footwear, stand upright, head, heels and buttocks against the wall or measuring instrument, look straight ahead, relaxed shoulder position and measured in a position to take a deep breath. Measurement of height and weight in adolescents is used to see tissue growth and growth velocity patterns. This information shows whether adolescent growth has increased or decreased. In practice, it is common to use percentiles to determine whether or not a body weight is ideal for height. Determination of nutritional status using the indicator of height for body weight is carried out by weighing body weight and measuring height, then calculating body weight (in $\mathrm{kg}$ ) compared to height (in $\mathrm{cm}$ ). 
Table 1. Classification of Body Weight Based on BMI in Adolescents According to Asia Pacific Criteria (Ministry of Health, 2014)

\begin{tabular}{ll}
\hline Classification & BMI (KG / M2) \\
\hline Less weight & $<18.5$ \\
Normal Range & $18.5-22.9$ \\
More weight & $\geq 23$ \\
It's risk & $23.0-24.9$ \\
Obesity I & $25-29.9$ \\
Obesity II & $\geq 30$ \\
\hline
\end{tabular}

Source: $\mathrm{MOH}(2014)$

Height and weight are the most commonly used measures because the equipment used is relatively simple and widely available. Scales, stadiometers and gauges of any kind should be calibrated periodically. In adults, height and weight are used together to calculate body mass index. BMI is recommended as a good indicator to determine nutritional status in adolescents, with the formula:

\section{Weight (kg)}

$\mathbf{B M I}=$

Height (m) X Height (m)

Table 2. BMI Threshold Categories for Indonesia

\begin{tabular}{lll}
\hline Category & \multicolumn{1}{c}{ Information } & BMI \\
\hline Very thin & Severe underweight & $<17$ \\
Thin & Mildly underweight & $17.0-18.4$ \\
Normal & & $18.5-25.0$ \\
Fat & Mildly overweight & $25.1-27.0$ \\
Obese & Being overweight & $>27.0$ \\
\hline
\end{tabular}

Table 3. Body Mass Index Category Shows Nutritional Status According to the World Health Organization (WHO)

\begin{tabular}{ll}
\hline Nutritional status & BMI (KG / M2) \\
\hline Underweight & $>18.5$ \\
Normal weight & $18.5-24.9$ \\
Pre-obesity & $25.0-29.9$ \\
Obesity class I & $30.0-34.9$ \\
Obesity class II & $35.0-39.9$ \\
Obesity class III & $>40$ \\
\hline
\end{tabular}

$\mathrm{BMI}$ has a positive correlation with total body fat, but BMI is not the only indicator to measure obesity. In addition to BMI, another method for anthropometric measurements of the body is by measuring the waist circumference. The International Diabetes Federation (IDF) issued criteria for abdominal circumference based on ethnicity.

Table 4. Waist Circumference Criteria Based on Ethnicity (Ministry of Health of the Republic of Indonesia)

\begin{tabular}{ll}
\hline Country / ethnic group & Waist circumference (cm) in obesity \\
\hline Europe & Male $>94$, Female $>80$ \\
South Asia, Population of $\quad$ China, & Male> 90, Female> 80
\end{tabular}


Malay and Asia-India

China

Japan

Central America

Sub-Saharan Africa

the middle East
Male> 90, Female> 80

Male> 85, Female> 80

Use South Asian recommendations,

until specific data are available

Use European recommendations to

specific data

Use European recommendations until

specific data are available

To see information about normal or obesity, a person is assessed first using the abdominal circumference device then measuring obesity by measuring his body mass index with the formula above and matching it in Table 1.

Body Mass Index (BMI) has advantages and disadvantages as an indicator for measuring body fat.

The advantage of the Body Mass Index (BMI) is a reliable indicator of measuring body fat in children and adolescents. BMI can be considered as an alternative to direct measurement of body fat. The measurement of BMI is assessed as only measuring data on body weight and height, cheap and easy to do and the reading results are according to the standard values stated in the BMI table and for screening in categorizing body weight that leads to health problems. The drawbacks of the Body Mass Index have its drawbacks. The weakness that occurs is in determining obesity. We know that obesity is excess body fat. BMI measures only body weight and height. Being overweight is not always synonymous with excess fat. Body weight consists of fat, water, muscle (protein).

In a very active person, for example an athlete, is inaccurate (especially development athletes) who tend to be obese, because they have excessive muscle mass even though the percentage of body fat is low, which is meant by a relatively low body fat composition and muscle composition. Relatively high, in a very active person a high BMI does not mean that they are overweight or not obese. And in children it is not accurate because the amount of body fat will change as a person grows and develops, so in children it is recommended to measure body weight based on sex and age.

\subsection{Blood Pressure}

Blood pressure is the force exerted by blood on the vessel walls. Blood pressure depends on the volume of blood contained in the vessel and compliance, or the distensibility of the vessel wall (how easily the vessel is stretched). If the volume of blood entering the arteries is equal to the volume leaving the arteries during the same period, the arterial blood pressure will be constant.

Pulmonary hypertension in daily clinical practice is often diagnosed at an advanced stage because the initial signs and symptoms are not specific. Although clinical assessment is very important in assessing patients who are suspected of having pulmonary hypertension, echocardiography is the main medium of choice in diagnostic enforcement. This examination provides an estimate of the value of the pulmonary artery pressure, both at rest and during exercise, and is also useful in screening for secondary causes of pulmonary hypertension. (Adhiany and Iqbal, 2020)

Systolic pressure (mean $120 \mathrm{mmHg}$ ) is the peak pressure generated by the burst of blood against the vessel walls during cardiac systole. Diastolic pressure (mean $80 \mathrm{mmHg}$ ) is 
the minimal pressure in the arteries when blood is channeled into the vessels downstream during the diastole. When the blood pressure is $120 / 80$, the pulse pressure (the difference between systolic and diastolic pressure) is $40 \mathrm{mmHg}$. Blood pressure classification or blood pressure for adults aged 18 years and over. Patients with prehypertension have a higher risk of developing hypertension. Those with a blood pressure range of 130-139 / 80-89 mmHg are at twice the risk of developing hypertension than those with lower scores. According to The Seventh Report of The Joint National Committee on Prevention, Detection.

Table 5. Classification of Blood Pressure According to JNC 7

\begin{tabular}{ll}
\hline Blood Pressure Classification & $\begin{array}{l}\text { Systolic and Diastolic Pressure } \\
(\mathbf{m m H g})\end{array}$ \\
\hline Normal & Systolic $<120$ (and) Diastolic $<80$ \\
Prehypertension & Systolic 120-139 (or) Diastolic 80-89 \\
Stage I hypertension & Systolic 140-159 (or) Diastolic 90-99 \\
Stage II hypertension & Systolic $\geq 160$ (or) Diastolic $\geq 100$ \\
\hline
\end{tabular}

World Health Organization (WHO) / International Society of Hypertension (ISH) (2003), the classification of high blood pressure is divided into optimal, normal, high normal, 1 st degree hypertension (mild), 2nd degree hypertension (moderate), 3rd degree hypertension (severe), and isolated systolic hypertension.

Table 6. Classification of High Blood Pressure According to WHO-ISH 2003

\begin{tabular}{|c|c|c|}
\hline Classification & $\begin{array}{l}\text { Systolic } \quad \text { blood } \\
\text { pressure }(\mathrm{mmHg})\end{array}$ & $\begin{array}{l}\text { Diastolic blood pressure } \\
(\mathrm{mmHg})\end{array}$ \\
\hline Optimal & $<120$ & $<80$ \\
\hline Normal & $<130$ & $<85$ \\
\hline High-Normal & $130-139$ & $85-89$ \\
\hline Grade1 Hypertension (mild) & $140-159$ & $90-99$ \\
\hline Subgroup: Borderline & $140-159$ & $90-94$ \\
\hline Grade 2 Hypertension (moderate) & $160-179$ & 100-109 \\
\hline Grade 3 Hypertension (severe) & $\geq 180$ & $\geq 110$ \\
\hline Subgroup: Borderline & $140-149$ & $<90$ \\
\hline
\end{tabular}

Changes in arterial pressure throughout the cardiac cycle can be measured directly by using a pressure gauge to which a needle is inserted into the artery. However, blood pressure can be measured indirectly more easily and fairly accurately using a sphygmomanometer and a stethoscope. The sphygmomanometer is composed of an expandable cuff and a blood pressure measuring device that corresponds to the inner cavity of the cuff. This tool is calibrated in such a way that the pressure read on the manometer matches the pressure in millimeters of mercury delivered by the brachial artery.

High blood pressure when sitting when the systolic pressure reaches $140 \mathrm{mmHg}$ or more, or the diastolic pressure reaches $90 \mathrm{mmHg}$ or more, or both. In high blood pressure, there is usually an increase in systolic and diastolic pressure. In isolated systolic hypertension, the systolic pressure reaches $140 \mathrm{mmHg}$ or more, but the diastolic pressure is less than 90 $\mathrm{mmHg}$ and the diastolic pressure is still within the normal range. 


\section{Research Methods}

This research is a descriptive study with a cross-sectional study design, namely how to approach, observe or collect data at the same time 10. This research was conducted by collecting data on height, weight and blood pressure to determine the description of body mass index and blood pressure among students of the Medan UNPRI medical faculty, class of 2017. This research will begin in October 2020. This research will be conducted on Jl. B elanga Campus 1 UNPRI Faculty of Medicine. The population in this study were all students of the medical faculty of UNPRI Medan, class of 2017.

The sampling technique is a sample selection process used in existing research, so that the number of samples will represent the entire population. In general, there are two types of sampling, namely probability sampling and non-probability sampling.

The sampling technique used in this study is to use purposive sampling, that each member or unit of the population has the same opportunity as the sample.

\subsection{Inclusion Criteria:}

a. UNPRI Medan medical faculty student batch of 2017 .

b. Age 20-25 years.

c. Willing to be a research subject.

\subsection{Exclusion Criteria:}

d. Not willing to be the subject of research.

e. Have a history of systemic disease

Table 7. Operaional Definition

\begin{tabular}{|c|c|c|c|c|}
\hline \multirow[t]{2}{*}{ No. } & \multirow[t]{2}{*}{ Variable } & \multirow{2}{*}{$\begin{array}{l}\text { Operational } \\
\text { definition }\end{array}$} & \multicolumn{2}{|c|}{ Measurin Measure Results Measure } \\
\hline & & & $\underset{\substack{\mathrm{instrumen} \\
\mathrm{t}}}{\mathrm{g}}$ & Scale \\
\hline 1. & $\begin{array}{l}\text { body mass } \\
\text { index }\end{array}$ & $\begin{array}{l}\text { Body Mass Index } \\
\text { (BMI) is a simple } \\
\text { index of body weight } \\
\text { for height used to } \\
\text { classify overweight } \\
\text { and obesity in } \\
\text { adults5 }\end{array}$ & $\begin{array}{l}\text { TB: } \\
\text { Microtoise } \\
\text { BB: Digital } \\
\text { scales }\end{array}$ & $\begin{array}{l}\text { 1. The status of Ordinal } \\
\text { very thin teeth } \\
\text { with BMI } \\
<17.0 \\
\text { 2. Static nutrition } \\
\text { thin with BMI } \\
\text { 17.0-18.4 } \\
\text { 3. Normal } \\
\text { nutritional } \\
\text { status with } \\
\text { BMI 18.5-25.0 } \\
\text { 4. Fat nutritional } \\
\text { status with } \\
\text { BMI> 25.0- } \\
\text { 27.0 } \\
\text { 5. Obese } \\
\text { nutritional } \\
\text { status with } \\
\text { BMI> 27.0 }\end{array}$ \\
\hline
\end{tabular}




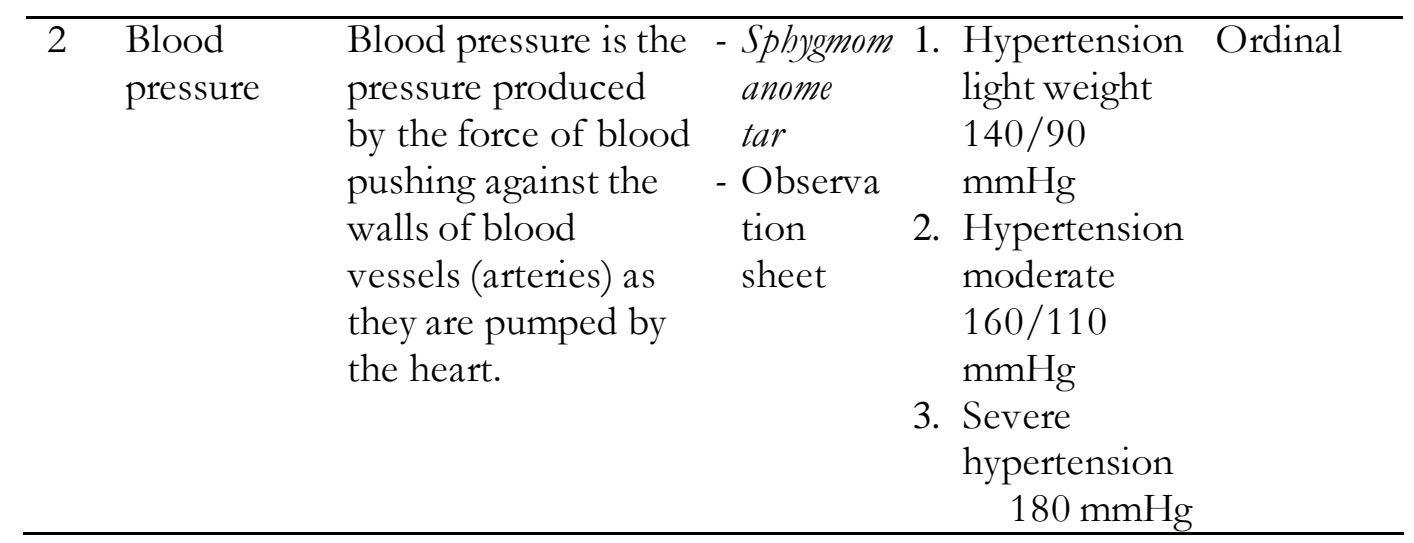

\section{Discussion}

The results of research on the frequency distribution of the students' at Faculty of Medicine, UNPRI Medan, class of 2017 can be seen in full in table 8 below.

Table 8. The Results of Research on the Frequency Distribution of the Students' at Faculty of Medicine, UNPRI Medan, Class of 2017

\begin{tabular}{ccc}
\hline Gender & Frequency & Percentage \\
\hline Male & 33 & 33.3 \\
Women & 66 & 66.7 \\
\hline Total & 99 & 100.0 \\
\hline
\end{tabular}

Based on table 8 above, the results of the study show that the majority of the sex of the 2017 UNPRI Medan Faculty of Medicine students are women, as many as 66 people $(66.7 \%)$, while men are only 33 people $(33.3 \%)$.

The results of research on the frequency distribution of the body mass index (BMI) of students of the Faculty of Medicine, UNPRI Medan, class of 2017 can be seen in full in table 9 below.

Table 9. Body Mass Index (BMI) Frequency Distribution

\begin{tabular}{ccc}
\hline BMI & Frequency & Percentage \\
\hline Underweight & 3 & 3.0 \\
Normal & 64 & 64.6 \\
Overweight & 29 & 29.3 \\
Obese & 3 & 3.0 \\
\hline Total & 99 & 100.0 \\
\hline
\end{tabular}

Based on table 9 above, the results show that the majority of students from the Faculty of Medicine UNPRI Medan class 2017 are normal, namely 64 people (64.6\%), followed by students with a BMI who are overweight 29 people $(29.3 \%)$, underweight and obese. each only 3 people $(3.0 \%)$. The results of research on the distribution of blood pressure frequencies for students of the Faculty of Medicine, UNPRI Medan, class of 2017 can be seen in full in table 10 below.

Table 10. Blood Pressure Frequency Distribution

\begin{tabular}{ccc}
\hline Blood pressure & Frequency & Percentage \\
\hline Normal & 99 & 100.0 \\
\hline Total & 99 & 100.0 \\
\hline
\end{tabular}


Based on table 10 above, the results of the study show that the majority of blood pressure students of the Faculty of Medicine UNPRI Medan class of 2017 are entirely normal $(100 \%)$.

In this study, it was found that most of the respondents had a normal BMI. The results of this study are in line with Kristantio \& Halim's (2019) research on students of the Faculty of Medicine at Tarumanagara University 2017 which stated that the majority of respondents' BMI was normal. It is also in accordance with the results of research by Sumia Aprilia et al (2014) on Tapak Suci Member Students at the Muhammadyah University of Surakarta which stated that 17 respondents out of 20 respondents had normal BMI. Body mass index (BMI) is a simple index and is used to determine whether someone is underweight, normal, overweight, or obese. This index describes the amount of intra-abdominal fat. In addition, body mass index or Body Mass Index is a measure that can estimate adiposity.

The results showed that all respondents had normal blood pressure. The results of this study are in line with research conducted by Pratama et al. (2015) on students of the Faculty of Medicine, University of Riau, class of 2012 and 2013 which stated that $63.22 \%$ of students had normal TDS with a value of $<120 \mathrm{mmHg}$ and $64.46 \%$ of students had TDD. Which is normal with a value of $<80 \mathrm{mmHg}$. In the Prastia study (2019) which revealed that the $2017 \mathrm{batch}$ of public health study program students had normal systolic blood pressure, diastolic prehypertension.

Blood pressure is the force generated by blood flow against the walls of blood vessels. Blood pressure consists of systolic blood pressure (TDS) which is blood pressure when the heart contracts, pumping blood around the body and diastolic blood pressure (TDD) which is blood pressure when the heart relaxes between two contractions. An increased body mass index indicates excess fat in the body, which can affect blood pressure by way of the sympathetic nervous system - the renin angiotensin system and vascular inflammation. Energy that is not used by the body is stored in the form of fat in the adipose tissue. These tissues which contain fat with atherogenic properties (total cholesterol, lipoprotein fractions, and triglycerides) stimulate vascular inflammation by inducing the release of cytokines, proinflammatory transcription factors, and adhesion molecules. Chronic inflammation is often associated with an increase in blood pressure categorized as a metabolic syndrome, which is an increase in systolic blood pressure equal to or exceeding $130 \mathrm{mmHg}$ and / or diastolic blood pressure equal to or exceeding $85 \mathrm{mmHg}$. Accumulation of fat in the blood vessel wall tissue can also cause atherosclerosis if endothelial dysfunction occurs. Atero plaque will cause thickening and hardening of the arterial walls so that it can interfere with the endothelial function of blood vessels and inhibit blood flow by clogging the opening of the blood vessels (narrowing of the arteries in the blocked part). This narrowing will increase the total peripheral resistance (TPR) which can further increase blood pressure slowly. Even though in this study, the body mass index of respondents was mostly normal, those with BMI who were overweight $(29.3 \%)$, underweight $(3 \%)$, and obese $(3 \%)$ needed attention. This is because the factors that can cause blood pressure to increase include food and body weight. People with obesity have the potential to suffer from hypertension because the arteries and veins are filled with fat, causing blood pressure to rise.

\section{Conclusion}

This study aims to determine the description of body mass index and blood pressure in students of the Faculty of Medicine, UNPRI, batch 2017. Some of the conclusions generated by this study are as follows: 
1. Based on the research results, it was found that the majority of BMI students from the Faculty of Medicine UNPRI Medan class 2017 were normal, namely 64 people $(64.6 \%)$, then followed by students with an overweight BMI of 29 people $(29.3 \%)$, underweight and obese respectively. only 3 people $(3.0 \%)$.

2. Based on the results of the study, it was found that the majority of the blood pressure of the 2017 UNPRI Medan Faculty of Medicine students was completely normal (100\%).

\section{References}

Adhiany, E and Iqbal, M. (2020). Diagnosis of Pulmonary Hypertension Using Ultrasonography in the Management of Critical Patients in the Intensive Care Unit. Budapest International Research in Exact Sciences (BirEx) Journal. P. 521-529

Aprilia S. Profil indeks massa tubuh dan v maksimum pada mahasiswa anggota Tapak Suci di Universitas Muhammadyah Surakarta. Naskah Publikasi. hhtp://eprints.ums.ac.id/31076/24/NASKAH_PUBLIKASI.pdf

Dien NG, Mulyadi, Kundre RM. (2014). Hubungan indeks massa tubuh (imt) dengan tekanan darah pada penderita hipertensi di Poliklinik Hipertensi dan Nefrologi BLU RSUP Prof. DR. R. D. Kandou Manado. Jurnal Keperawatan.;9(2):7.

Departemen Kesehatan Republik Indonesia. Pedoman Status Gizi. In: Masyarakat DJK, ed. Pedoman Status Gizi. ; 2014.

Dhara S, Chatterjee K.(2015). A Study of VO2 Max in Relation with Body Mass Index (BMI) of Physical Education Students. Res J Phys Educ Sci;3(6):9-12. www.isca.me.

Elex Media Komputindo. Seri Diet Korektif - Diet South Beach. https:/ / books.google.co.id/books?id=OR9bDwAAQBAJ\&printsec $=$ frontcover\&hl=i $\mathrm{d} \# \mathrm{v}=$ onepage $\& \mathrm{q} \& \mathrm{f}=$ false.

Fitriani N, Nilamsari N. (2017). Factors associated with blood pressure on shift workers and non-shift workers in Pt. X Gresik. J Ind Hyg Occup Heal.;2(1):57. doi:10.21111/jihoh.v2i1.1273

Green L. (2003). JNC 7 express: new thinking in hypertension treatment. Am Fam Physician.;68(2).

Kemenkes. Mengukur Status Gizi Dengan Indeks Massa Tubuh. 2011;2:1-4. http://staffnew.uny.ac.id/upload/132318122/pendidikan/BAHAN+AJAR+IMT.pdf.

Kemenkes RI. (2013). Pedoman Teknis Penemuan dan Tatalaksana Hipertensi.

Kristantio JE, Halim S. (2019). Hubungan indeks massa tubuh dengan tekanan darah pada mahasiswa Fakultas Kedokteran Universitas Tarumanagara 2017. Tarumanagara Medical Journal.;2(1):59-64.

M, Adriani. B W. (2016). Peranan Gizi dalam Siklus Kehidupan. J Chem Inf Model.;53(9):1689-1699. doi:10.1017/CBO9781107415324.004

Nuraini B. (2015). Risk Factors of hypertension. Medical J of Lampung University.;4:10-19.

Pastia TN. (2018). Gambaran tekanan darah dan indeks massa tubuh pada mahasiswa prodi kesmas angkatan 2017 Fikes Uika Bogor tahun. Promotor Jurnal Mahasiswa Kesehatan Masyarakat. 2019;2(3):234-239.

P2PTM Kemenkes RI. (2018). Bagaimana cara menghitung imt (indeks massa tubuh). 06 November http://p2ptm.kemkes.go.id/infographic/bagaimana-cara-menghitung-imtindeks-massa-tubuh.

P2PTM Kemenkes RI. Yuk, cek indeks massa tubuh (IMT). 06 September 2019. http://p2ptm.kemkes.go.id/infographic/yuk-cek-indeks-massa-tubuh-imt.

Penyakit I, Lingkungan P. (2006). Pedoman Teknis Penemuan dan Tatalaksana Penyakit Hipertensi. http://perpustakaan.depkes.go.id:8180/handle/123456789/742. 
Pratama BJ, Christianto E, Bebasari E. (2015). Korelasi indeks massa tubuh dengan tekanan darah pada mahasiswa Fakultas Kedokteran Universitas Riau angkatan 2012 dan 2013. JOM FK.;2(2):1-10.

Rossner S. Kelebihan Berat Badan dan Obesitas. In J. Mann, \& A. S. Truswell, Buku Ajar Ilmu Gizi (pp.251 - 257). Jakarta: Buku Kedokteran EGC. 2014.

Sherwood L. Fisiologi Manusia: Dari Sel Ke Sistem, Ed. 8.; 2014.

Supariasa IDN, Bakri B, Fajar I. Penilian Status Gizi. 2 ed. Jakarta: EGC; 2001.

Universitas Muhammadiyah Purwokerto. Program Studi Teknik Informatika BJ, Pinandita T. Juita. Juita. 2011;I(4):157-168. https://www.neliti.com/publications/92701/rancangbangun-aplikasi-mobile-perhitungan-indeks-massa-tubuh-dan-berat-badan-id. 